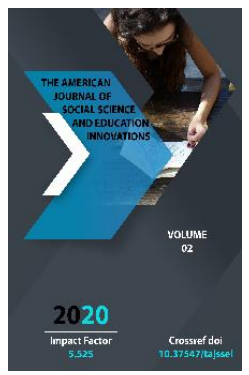

\title{
Resettlement Policy Of The Russian Empire: A Historical Analysis (On The Example Of The Fergana Valley!)
}

Kurbonova N.N.

Associate Professor, Humanities Department, Andijan Machine Building Institute, Uzbekistan

Journal Website:

http://usajournalshub.c

om/index,php/tajssei

Copyright: Original

content from this work may be used under the terms of the creative commons attributes 4.0 licence.

\section{ABSTRACT}

The article reveals the resettlement policy of the Russian Empire in Turkestan using the example Fergana Valley: in addition, it shows the social status of dehkans (farmers) and discontent against the colonial policy of the empire. The need for the growth of raw materials is consecrated on the basis of archival materials.

\section{KEYWORDS}

Resettlement, revolt, raw materials, market, peasants, Cossack population of cotton breeding.

\section{INTRODUCTION}

Since the beginning of the military expansion to Central Asia the Russian Empire along with the establishment its influence in the Bukhara Emirate and Kokand the khanate pursued other goals: in particular, mastery of territories with high potential for growing cocoons and cotton, and also rich in underground minerals; transformation of colonized territories into large town for the implementation of Russian ready-made products; use of local people in the quality of cheap labor; Besides, there were also strategic reasons: (entering new borders with China and Iran, direct proximity to the Afghan 
border). In the highest political and military circles

The Russian Empire was well aware that for holding in the occupied territories Central Asian colonial policy and turning them into a source of raw materials and natural agricultural wealth rely only on military force and the system of administrative management is impossible, since indigenous peoples regions were mentally prepared to defend their historical national identity and moral values from Encroachments of other states, to fight against dependence on them therefore, along with the development of the conquest Central Asia was envisaged in the first turn on preferential terms to relocate to occupied territories leading paramilitary

Cossack lifestyle, then arrange here Russians and Ukrainians. Cossacks, who always had weapons (sabers, guns), and those who moved after their population should have become strong and reliable support for suppressing local riots peoples.

\section{MAIN PART}

Most of the authors of works devoted to socio-economic policy of the Russian empire in the Turkestan region, and in particular empire officials explained the need resettlement of Russians to Turkestan, allegedly in the inner provinces of excessive agricultural population resulting from the abolition serfdom system, and the need for relocating it to the norms of the territory. But given the approach is not even partially correct, because, firstly, from the Russian Empire many Cossacks and part of the Christian urban population were relocated to the previously captured Caucasus; secondly, even before abolition of serfdom, in the 50 s of the XIX century following the invasion of Russian troops on the ground Kokand Khanate (Priaralye, Kazalinsk, Ak- mosque, Issyk-Kul basin, Tokmak, Pishpek, Semirechye) and Khiva Khanate (peninsula Mangyshlak, Caspian steppes) many Russian was located here in the rural terrain in such comfortable conditions for life, which were not even in the metropolis; thirdly, the problem surplus agrarian population could be to decide by resettlement not to Central Asia, but to sparsely populated inner provinces either Far East or Eastern Siberia. By in in this case, the priority was given to the principles associated with Central Asia. If the conquest The Caucasus provided Russia, from the point of view economic, mastering oil fields, and from the point of view of strategic - moving towards the borders of Iran and Turkey and strengthening their positions in the Caspian Sea, then establishment of colonial rule in Central Asia gave above all the possibility of purchasing agricultural raw materials (cotton fiber, cocoons, livestock products) and mineral resources required for the industry of the metropolis, the development of new market for the sale of their finished products, access to the borders of Afghanistan and expansion existing borders with Iran and China.

Therefore resettlement of "surplus" population was necessary to strengthen the strategic positions [1]. In our opinion, an important the role was played here also by Russian-English rivalry. The Russian Empire and its officials- colonists,

Fergana Valley, Khiva capturing new territories of the Bukhara Emirate and Khanate, until 1881 controlled the number, social or ethnic composition of the population who moved in large numbers from Russia to Turkestan. However, much attention was paid to resettlement and construction of settlements in strategically important areas for Cossacks and other Christians. Initially, the 
policy of resettlement of Russians to the territory of the region was carried out by force. Then the number of people resettling voluntarily began to increase [2], among the Russian population, who moved on their own in the hope of getting rich in a new place, there were many urban and rural poor. The district authorities noted the complication of the problem of accommodating the poor and needy representatives of the resettled Slavic population due to their large number [3] The head of the Andijan district reported to the military governor of the Fergana region in September 1910: "In various provinces of Russia there were many ordeals who found themselves in the position of lumpen, but most of them, having neither horse nor land, nevertheless seriously wishes to settle down here. The attitude of Russian peasants to the local population cannot be called benevolent. In most cases, they disdain the natives and insult them groundlessly"[4]. Since the founding of Fort No. 1 (originally Whitemosque, later Perovskiy, now Kyzyl-Orda), the resettlement of the Russian population took place in relatively comfortable conditions. Since 1847 , when two regiments of military Siberian Cossacks arrived in Semirechye, the Cossack population, leading a paramilitary lifestyle, began to move to the Turkestan Territory. During this period, the influx of the Christian population, who moved here in response to the call of the government and in most cases of their own free will, was taken under strict control and to a certain extent was controlled. The resettled Christian population was exempt from all types of taxes and was provided in cities with housing and work, in rural areas - arable land and pastures taken from the local population. In the official document of the Governor-General of Turkestan K.P. Kaufman, sent to the government in 1873, it was proposed to send part of the Russian population from Orenburg to Tashkent and then from Tashkent to transport it through Verny (currently Almaty) to the territory located from Verny to Semipalatinsk [five] envisaging further strengthening the flow of the Christian population to the marginal territories, the government of the empire and the governorgeneral of Turkestan decided to issue 10 acres of land and material assistance in a certain amount for each man in each resettled family.

This proposal, in augmented form, was adopted in 1876 after the capture of the Fergana Valley. The fact is that if the second direction indicated by Kaufman, that is, the path from Tashkent to Semipalatinsk, was initially recognized as more convenient, but now, after the fall of the Kokand Khanate and the establishment of a Russian protectorate over the Bukhara Emirate and the Khiva Khanate, and also in view of the appearance of the possibility of transformation the region into a source of agricultural raw materials, primarily for the cultivation of cotton, for the resettlement of the Russian population, the priority directions were from Orenburg through Tashkent and Khojent to Osh and Jalalabad, and also through Khavaed (at that time Ursatyevsk) to Jizzak, Samarkand and the Amu Darya branch. At the same time, the possibility of settling the Cossacks only on the lands bordering Afghanistan, Iran and China was established, and it was strictly forbidden to issue the Berdanka rifles to the German population resettled in the territory of the region.

On July 10, 1881, the Emperor of Russia signed the first document related to the resettlement of the population - "Temporary Provisions on the Resettlement of Peasants to Free State Lands." According to these provisions, [6] the official church Protestants had previously headed west. Now the Slavs belonging to 
various sects, as well as the Germans members of the Baptist and Mennonite sects have expressed their hope to find refuge in Central Asia.

It is known that in the 1880s, 30 families of Russian Mennonites, with the permission of the Khiva Khan, were settled not far from the Amu Darya. But the Russian Empire doubted that Christians who did not profess Orthodoxy would be the mainstay of the colonial policy in Turkestan, and in 1883 new provisions on population resettlement were adopted. From now on, only Russians, Ukrainians and Belarusians professing Orthodoxy had the right to move to the region. At the same time, the size of the area allocated to resettling families of land was reduced, especially in the Fergana and Samarkand regions [7].

In 1886, 1889, 1892, 1903 and 1910, the Russian Empire adopted special regulations on the resettlement of the Christian Orthodox population in Turkestan, seeking to organize in an organizational manner to send here in a larger number of Russian Orthodox peasants and urban workers from the economically and socially backward provinces of Russia. However, the difficult economic situation in the provinces and the widespread feeling of great-power chauvinism among the Russian population, as well as the desire to quickly get rich in the territories controlled by Russia at the expense of the local population, led to the fact that a huge number of people moved to Central Asia without any permission.

For example, due to the fact that the Fergana region was ahead of other regions in terms of cotton ginning industry, oil production, silkworm breeding, textile industry, oil production and mining, the situation of Russian peasants living here in rural areas differed from the situation of those living in other territories. For example, in the village of Nikolaevskoye in the Andijan district and in the village of Uspenskoye in the Namangan district, each farm had 14.5 tithes of land suitable for sowing and 3 tithes of pastures. By 1889 , the number of landless and land-poor peasants and entrepreneurs had increased to such an extent that the Russian government in 1889 introduced a law controlling the development of state lands by the migrant rural population. After that, for some time, the resettlement policy was suspended and intensified again after the uprisings in 1892 in Tashkent and in 1898 in Andijan [8]. As a result, thanks to the material with the help of resettlement institutions, the number of Russians resettled to Turkestan in comparison with those who arrived unauthorizedly increased 2 to 3 times, in some localities in smaller proportions. For those resettled in the Syrdarya, Samarkand, Trans-Caspian, Fergana regions of the Turkestan Territory, 6,000 acres of land were allocated, taken from the local population [9].

The Russian Empire, pursuing its own interests, was not limited only to the resettlement of the population to Turkestan, but also after the fall of the Kokand Khanate in 1881 , it entered into an agreement with the Chinese government, which planned to include the lands of eastern Turkestan (currently the Xinjiang Uygur Autonomous Okrug) into the state, and agreed to resettle the Uyghur and Dungan population to the Andijan and Osh districts of the Fergana region. In 1883 alone, more than 60 thousand Uighurs, Dungans and representatives of other Muslim peoples were resettled from East Turkestan, but the colonial institutions gave them permission only to cross the border, their resettlement and the provision of material assistance to them was completely entrusted to the local population. 
The Armenians, who moved to the TransCaspian region in 1894, settled in Ashgabat, Samarkand, Kokand, Andijan and other cities within 5-6 years. From Kashkar, which was under the oppression of the Chinese government, the influx of Muslim refugees into the Fergana region increased again at the beginning of the 2oth century. In 1905, 14556 were resettled, in 1905 - 13337, in 1907 - 25056, in 1909 - 12725, in 1911-1912 - 53,637 Uzbeks, Uyghurs, Dungans, Kazakhs, Kyrgyz and representatives of other Muslim nations and ethnic groups. The issues of their resettlement were also entrusted to the aksakals ( elder men) of oases and kishlaks. The influx of the Russian population to regions with irrigated lands like the Fergana Valley, especially to regions with developed cotton and silkworm growing, led to the fact that tax benefits provided to Russian peasants were covered by additional taxes levied on local farmers, as well as various extortions, what caused their landlessness and national profanation and turned out to be the main reason for the riots and large and small uprisings of the indigenous population. In view of the refusal of the peoples of the region to obey the colonial policy and the dissatisfaction of the local population with the great-power moods of the resettled population, the Russian Empire and the administration of Turkestan, long before the uprisings in Tashkent (1892) and Andijan (1898), paid special attention to arming the Russian rural population with simple rifles ("berdanks "), The organization of military detachments in Russian, Ukrainian and Belarusian settlements and the regular establishment among the Muslim population of dubious persons dangerous for the government and monitoring them.

Local aksakals were also involved in this. After the Andijan uprising the new military governor of the Fergana region, Major General Tchaikovsky, sent a report to the emperor of Russia, in which he wrote about the political situation, in particular the following: "After the riot of Ishan Mingtepa, on May 18, 1898, order was established in the region and there was no discontent. Ishan's plans did not have time to put down deep roots, and there were few unreasonable participants in this unwanted incident. The population is well aware of the humanity of the leadership and the power of the empire. However, the danger of manifestation of discontent against us remains, and therefore the Russian administration needs to strengthen control of all areas of the life of the local population.

Unfortunately, the fulfillment of such a necessary task is hampered by the small number of administrative posts in the region. In five counties with a population of $1 \mathrm{~L}$ million people, there are only 17 people, organizing their administrative and police control, of which only 7 people (district inspectors) live among the local population; the other 10 live in the city ... heads of volosts and rural aksakals are not sufficiently reliable and independent to perform police duties ... it is necessary to relocate as many Russians as possible who are engaged in agriculture from the inner provinces of the empire. "

On the eve of World War I, on July 28, 1914, the military governor of the Fergana region, in his report to the governor-general of the region, stated, in particular, the following: "population in connection with the impending outbreak of war and the withdrawal of troops, in view of which, in order to defend the Russian population, he asks to give them weapons .... Through the fault of the Russians, the local population is outraged. The head of the Andijan district is also alarmed, knowing that the uprising you know is still alive in the 
memory of the indigenous population. Therefore, I ask during the war to leave some troops in the cities of Andijan, Osh and Kokand, and also immediately transfer one of the hundreds located in the city of Skobelev to Andijan."

In the early days of the war, the military governor of Fergana gave the heads of the districts an order to issue the population of Russian settlements and their teams with Berdan guns and bullets. On August 12, 1914, the acting governor-general, LieutenantGeneral Flug, wrote to all the military generals of the regions: "If necessary, I ask you to organize self-defense of the Russian population and submit your thoughts to me. It is necessary to keep in mind ensuring the use of weapons, their storage and prevention of their transfer into the wrong hands. "

Since 1915, thousands of foreign prisoners of war (Hungarians, Slovaks, Romanians, Poles, Germans, Turks and others) were driven into Turkestan and resettled mainly in rural areas, and an influx of refugees from the regions began. located near the Western Front. A mandatory military tax began to be levied on the indigenous population. This turned out to be a heavy burden for the local population. Suffering defeats on the Western Front, the Russian Empire, in order to overcome the military-political crisis, among other measures, considered it necessary to attract local men from Turkestan aged 19 to 43 to organize defenses behind the front line and industrial work, and the Tsar on June 25, 1916 announced the corresponding decree. General Galkin was entrusted with ensuring the practical implementation of this decree in the region. From Turkestan, 250 thousand workers should have been sent to the western regions of the empire, including 77 thousand from Fergana region. The practical implementation of the decree was the impetus and at the same times the reason for the start of the general popular uprising in 1916.

\section{CONCLUSION}

After the Andijan uprising, the leadership of the empire, paying special attention to the social composition of the population migrating from the metropolis, in every possible way ignoring the interests and rights of the indigenous people, increased socioeconomic and nationalist pressure, but during this period a lot of educated people appeared in the region, thinking in a new way and deeply aware of the prospects for the development of the people and the nation. This became the most important factor in enriching the experience of the struggle for independence of the indigenous population of Turkestan and, in particular, of the Fergana Valley.

\section{REFERENCES}

1. Musaev N. The second half of the XIX century - the beginning of the $X X$ century. TamKernqlconom-Finance, 2008 , p. 12. (Formation of industrial production in Turkestan in the second half of the XIX - early XX century). Tashkent iqtisod-moliya, 2008, p. 12.

2. Musaev N. The second half of the XIX century - the beginning of the $\mathrm{XX}$ century. TamKernqlconom-Finance, 2008, p. 12. (Formation of industrial production in Turkestan in the second half of the XIX - early XX century). Tashkent iqtisod-moliya, 2008, p. 22.

3. Musaev N. The second half of the XIX century - the beginning of the $X X$ 
century. TamKernqlconom-Finance, 2008, p. 12. (Formation of industrial production in Turkestan in the second half of the XIX - early XX century). Tashkent iqtisod-moliya, 2008, p. 43.

4. Musaev N. The second half of the XIX century - the beginning of the $\mathrm{XX}$ century. TamKernqlconom-Finance, 2008 , p. 12. (Formation of industrial production in Turkestan in the second half of the XIX - early XX century). Tashkent iqtisod-moliya, 2008, p. 48.

5. Musaev N. The second half of the XIX century - the beginning of the $\mathrm{XX}$ century. TamKernqlconom-Finance, 2008, p. 12. (Formation of industrial production in Turkestan in the second half of the XIX - early XX century). Tashkent iqtisod-moliya, 2008, p. 50.

6. Musaev N. The second half of the XIX century - the beginning of the $\mathrm{XX}$ century. TamKernqlconom-Finance, 2008, p. 12. (Formation of industrial production in Turkestan in the second half of the XIX - early XX century). Tashkent iqtisod-moliya, 2008, p. 54.

7. Musaev N. The second half of the XIX century - the beginning of the $\mathrm{XX}$ century. TamKernqlconom-Finance, 2008, p. 12. (Formation of industrial production in Turkestan in the second half of the XIX - early XX century). Tashkent iqtisod-moliya, 2008, p. 56.

8. Musaev $\mathrm{N}$. The second half of the XIX century - the beginning of the $X X$ century. TamKernqlconom-Finance, 2008 , p. 12. (Formation of industrial production in Turkestan in the second half of the XIX - early XX century). Tashkent iqtisod-moliya, 2008, p. 60.

9. Musaev N. The second half of the XIX century - the beginning of the $X X$ century. TamKernqlconom-Finance, 2008, p. 12. (Formation of industrial production in Turkestan in the second half of the XIX - early XX century). Tashkent iqtisod-moliya, 2008, p. 65. 